\title{
Pengaruh Waktu Penyiangan terhadap Pertumbuhan dan Hasil Dua Kultivar Kedelai (Glycine max (L.) Merr.)
}

\section{The Effect of Weeding Frequencies on Growth and Yield of Two Soybean Cultivars (Glycine max (L.) Merr.)}

\author{
Kurnia Dyah Puspita ${ }^{1)}$, Dyah Weny Respatie ${ }^{2^{*}}$, dan Prapto Yudono ${ }^{2)}$ \\ 1) Program Studi Agronomi, Fakultas Pertanian, Universitas Gadjah Mada \\ 2) Departemen Budidaya Pertanian, Fakultas Pertanian, Universitas Gadjah Mada \\ $\left.{ }^{*}\right)$ Penulis untuk korespodensi E-mail: wenyrespatie@ugm.ac.id
}

\begin{abstract}
Fields experiments were conducted at Banguntapan Experimental Field, Faculty of Agriculture, Gadjah Mada University, Yogyakarta from November 2015 to February 2016. This study was aimed to determine the effect of the weeding frequencies on growth and yield of two soybean cultivars, to determine critical period of two soybean cultivars, and to determine dominant weed composition on soybean crops. The research was arranged in Split Plot design, consisted of two factors. The main plot was kinds of soybean cultivars that consisted of two levels (Grobogan and Agromulyo). Then the sub plot was weeding frequencies that consisted of eight levels (Weeding until 2, 4, 6 weeks, and at harvested, and without weeding until 2, 4, 6 weeks, and at harvested). The results showed that weeding frequencies have effect to growth and yield of two soybean cultivars. Critical period of two cultivars was between 0-6 weeks after planting. The dominant weed on Grobogan soybean crops is Bulbostylis puberula. The dominant weed on Argomulyo soybean crops is Cyperus rotundus.
\end{abstract}

Keywords: soybean cultivar, weed, weeding frequencies

\section{INTISARI}

Penelitian ini bertujuan untuk mengetahui pengaruh waktu penyiangan terhadap pertumbuhan dan hasil dua kultivar kedelai, menentukan periode kritis dua kultivar kedelai dan mengetahui komposisi gulma dominan pada pertanaman dua kultivar kedelai.Penelitian dilaksanakan pada bulan November 2015 - Februari 2016 di Kebun Percobaan, Fakultas Pertanian, Universitas Gadjah Mada, Yogyakarta. Penelitian menggunakan Rancangan Split Plot 2 faktor yaitu kultivar kedelai (Grobogan dan Argomulyo) sebagai petak utama dan perlakuan waktu penyiangan (penyiangan sejak tanam hingga umur 2, 4, 6 minggu dan panen, serta tanpa penyiangan sejak tanam hingga umur 2, 4, 6 minggu, dan panen) sebagai anak petak. Hasil penelitian menunjukkan bahwa waktu penyiangan berpengaruh terhadap pertumbuhan dan hasil dua kultivar kedelai. Penyiangan yang dilakukan pada periode kritis tanaman kedelai menunjukkan pertumbuhan dan hasil yang lebih baik dibandingkan dengan tanaman kedelai yang tidak dilakukan penyiangan. Periode kritis tanaman kedelai kultivar Grobogan dan kultivar Argomulyo yaitu pada umur 0-6 minggu setelah tanam. Gulma yang dominan pada pertanaman kedelai Grobogan yaitu Bulbostylis puberula. Gulma yang dominan pada pertanaman kedelai Argomulyo yaitu Cyperus rotundus.

Kata kunci: kultivar kedelai, gulma, waktu penyiangan 


\section{PENDAHULUAN}

Kedelai merupakan salah satu komoditas pertanian yang banyak dibudidayakan dan menjadi salah satu tanaman prioritas nasional. Menurut Atman (2006) kedelai (Glycine max (L.) Merr.) merupakan salah satu komoditas pangan bergizi tinggi sebagai sumber protein nabati dan rendah kolesterol dengan harga terjangkau.Kebutuhan kedelai terus meningkat karena pertambahan penduduk, juga meningkatnya konsumsi per kapita terutama dalam bentuk olahan dan tumbuhnya industri pakan ternak (Siregar, 2003).

Kebutuhan kedelai pada tahun 2013 mencapai 2.198.200 ton sedangkan ketersediaan kedelai hanya mencapai 780.000 ton. Pada tahun 2014, permintaan kedelai meningkat menjadi 2.235 .600 ton tetapi ketersediaan kedelai hanya mencapai 921.300 ton. Produktivitas kedelai nasional meskipun mengalami peningkatan tetapi saat ini masih tergolong sangat rendah, yaitu 1,5 ton/ha. Padahal potensi produktivitas kedelai masih dapat ditingkatkan hingga 2,5 ton/ha melalui pemanfaatan teknologi maju dan pemeliharaan yang intensif. Selain berkurangnya ketersediaan lahan, kehadiran gulma di sekitar tanaman budidaya juga merupakan faktor penyebab penurunan produksi kedelai(Sudaryanto dan Swastika, 2007).

Gulma merupakan tumbuhan yang tumbuh di suatu tempat dalam waktu tertentu yang tidak diinginkan oleh manusia sehingga menimbulkan kerugian bagi tujuan manusia. Keberadaan gulma dapat menurunkan kualitas dan kuantitas hasil panen tanaman budidaya. Keberadaan gulma menyebabkan kompetisi yang tinggi (ruang, air, udara, dan unsur hara) antara tanaman yang dibudidayakan dengan gulma. Gulma tidak dikehendaki karena bersaing dengan tanaman yang dibudidayakan dan dibutuhkan biaya pengendalian yang cukup besar yaitu sekitar $25 \%-30 \%$ dari biaya produksi (Soerjani et al., 1996).

Menurut Moenandir (1993) penyiangan merupakan cara pengendalian gulma yang sangat praktis, aman, efisien, dan murah jika diterapkan pada suatu area yang tidak luas dan di daerah yang cukup banyak tenaga kerja. Pemilihan waktu penyiangan yang tepat dapat mengurangi jumlah gulma yang tumbuh serta dapat mempersingkat masa persaingan. Kehadiran gulma di sepanjang siklus hidup tanaman budidaya tidak selalu berpengaruh negatif. Terdapat suatu periode ketika gulma harus dikendalikan dan terdapat periode ketika gulma juga dibiarkan tumbuh karena tidak mengganggu tanaman (Moenandir, 1993). Periode hidup tanaman yang sangat peka terhadap kompetisi gulma ini disebut periode kritis tanaman. 
Kurnia Dyah Puspita et al., / Vegetalika. 2017. 6(3): 24-36

Periode kritis persaingan dengan gulma adalah periode pertumbuhan tanaman yang sangat rentan terhadap gangguan gulma. Dengan diketahui periode kritis tanaman, pengendalian gulma menjadi efisien sebab hanya terbatas pada awal periode kritis, tidak harus pada seluruh siklus hidup tanaman. Pada awal pertumbuhan tanaman sudah terjadi kompetisi antara tanaman dengan gulma. Pengendalian gulma pada periode ini paling efisien dan efektif karena memberikan kesempatan bagitanaman budidaya untuk tumbuhdan menguasai ruang tumbuh.

Menurut Zimdahl (2004) periode kritis tanaman terjadi pada 25\% sampai 33\% pertama dari siklus hidup tanaman, sedangkan Mercado (1979) menyatakan bahwa periode kritis pertanaman berkisar antara $33 \%$ sampai $50 \%$ dari umur tanaman. Penurunan hasil akibat gulma pada tanaman kedelai dapat mencapai $18 \%-76 \%$ (Manurung dan Syam'un, 2003). Penentuan periode kritis dilakukan untuk mengurangi penurunan hasil akibat gulma serta mengetahui saat yang tepat untuk melakukan pengendalian.

\section{BAHAN DAN METODE}

Penelitian dilaksanakan pada bulan November 2015 - Februari 2016 di Kebun Percobaan, Fakultas Pertanian, Universitas Gadjah Mada, Yogyakarta. Bahan penelitian yang digunakan adalah benih kedelai (Glycine max (L.) Merr.) kultivar lokal Grobogan dan Argomulyo, pupuk kandang, TSP, $\mathrm{KCl}$, dan urea. Alat yang dibutuhkan yaitu alat tulis, penggaris, spidol, timbangan, gembor, cangkul, cetok, frame (bingkai) kawat berukuran $50 \mathrm{~cm} \times 50 \mathrm{~cm}$, kamera digital, oven,Termohigrometer.

Rancangan percobaan yang digunakan yaitu Rancangan Split Plot yang terdiri dari dua faktor yaitu kultivar kedelai sebagai petak utama dan perlakuan waktu penyiangan sebagai anak petak. Kultivar kedelai yang digunakan yaitu Grobogan dan Argomulyo. Perlakuan yang digunakan yaitu penyiangan yang dilakukan sejak tanam hingga tanaman berumur 2 minggu, 4 minggu, 6 minggu, dan panen, serta tanpa penyiangan sejak tanam hingga tanaman berumur 2 minggu, 4 minggu, 6 minggu, dan panen. Percobaan ini menggunakan tiga blok sebagai ulangan untuk masing-masing kultivar. Masing-masing blok terdiri atas 8 petak percobaan (setiap petak mewakili satu kombinasi perlakuan), sehingga akan didapatkan 48 petak percobaan. 
HASIL DAN PEMBAHASAN

Tabel 1. Data pengambilan sampel gulma sebelum olah lahan

\begin{tabular}{lccccc}
\hline \multirow{2}{*}{ Nama Gulma } & Jenis & \multicolumn{3}{c}{ SDR \% } & \multirow{2}{*}{ SDR (\%) } \\
\cline { 3 - 4 } Tridax procumbens & Gulma & Blok 1 & Blok 2 & Blok 3 & \\
Cyperus rotundus & $\mathrm{D}$ & 13,60 & 25,07 & 16,36 & 18,35 \\
Lindernia ciliata & $\mathrm{T}$ & 12,71 & 19,31 & 11,65 & 14,56 \\
Lindernia crustacea & $\mathrm{D}$ & 9,66 & 16,29 & 12,88 & 12,94 \\
Paspalum dilatatum & $\mathrm{D}$ & 5,57 & 14,90 & 15,28 & 11,92 \\
Euphorbia hirta L. & $\mathrm{R}$ & 7,87 & 13,29 & 11,76 & 10,97 \\
Cynodon dactylon & $\mathrm{D}$ & 10,60 & 3,12 & 12,61 & 8,78 \\
Ochimum sanctum & $\mathrm{R}$ & 17,56 & 0,00 & 0,00 & 5,85 \\
Ricardia scabra & $\mathrm{D}$ & 8,41 & 3,13 & 3,32 & 4,95 \\
Paspalum conjugatum & $\mathrm{D}$ & 0,00 & 4,87 & 9,20 & 4,69 \\
Bulbostylis puberula & $\mathrm{R}$ & 7,17 & 0,00 & 3,25 & 3,47 \\
Mimosa sp. & $\mathrm{T}$ & 3,73 & 0,00 & 0,00 & 1,24 \\
Dismodium sp. & $\mathrm{D}$ & 0,00 & 0,00 & 3,69 & 1,23 \\
\hline Total & $\mathrm{D}$ & 3,12 & 0,00 & 0,00 & 1,04 \\
\hline Keterangan : D : daun lebar, T : tekian, R : rumputan & 100,00 & 100,00 & 100,00 & 100,00 \\
\hline
\end{tabular}

Pengambilan sampel gulma sebelum dilakukan pengolahan lahan bertujuan untuk mengetahui gulma yang dominan di lahan tersebut. Berdasarkan tabel 1 terdapat 13 macam gulma yang berada di lahan tempat penelitian dilakukan. Berdasarkan hasil analisis gulma dapat diketahui bahwa nilai SDR tertinggi pada gulma Tridax procumbens dengan nilai SDR sebesar 18,35\%. Tridax procumbens termasuk golongan gulma berdaun lebar.

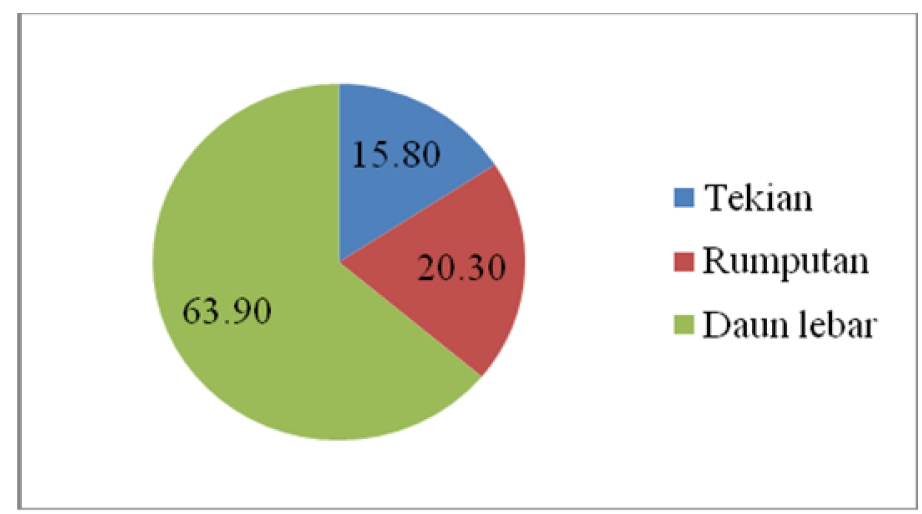

Gambar 1. Diagram komposisi gulma sebelum olah lahan

Gambar 1 menunjukkan diagram komposisi gulma sebelum dilakukan pengolahan lahan. Gulma yang dominan di lahan tersebut yaitu gulma berdaun lebar. Hal ini ditunjukkan dari nilai SDR yang tinggi dibandingkan dengan jenis gulma yang lain. 
Kurnia Dyah Puspita et al., / Vegetalika. 2017. 6(3): 24-36

Tabel 2. Data pengambilan sampel gulma kedelai Grobogan

\begin{tabular}{lcccc}
\hline \multicolumn{1}{c}{ Nama Gulma } & Jenis & \multicolumn{3}{c}{ SDR (\%) } \\
\cline { 3 - 5 } & gulma & 2 minggu & 4 minggu & 6 minggu \\
\hline Bulbostylis puberula & $\mathrm{T}$ & 29,01 & 37,25 & 29,34 \\
Cyperus rotundus & $\mathrm{T}$ & 14,41 & 12,23 & 0,00 \\
Digitarias sp. & $\mathrm{R}$ & 12,26 & 0,00 & 3,55 \\
Cynodon dactylon & $\mathrm{R}$ & 10,18 & 8,62 & 11,39 \\
Richardia scabra & $\mathrm{D}$ & 9,03 & 0,00 & 8,58 \\
Phyllanthus niruri & $\mathrm{D}$ & 6,78 & 5,83 & 8,93 \\
Cyperus iria & $\mathrm{T}$ & 4,03 & 9,51 & 8,93 \\
Portulaca oleraceae & $\mathrm{D}$ & 3,49 & 6,11 & 0,00 \\
Ageratum conyzoides & $\mathrm{D}$ & 3,26 & 0,00 & 0,00 \\
Amaranthus spinosus & $\mathrm{D}$ & 2,86 & 2,35 & 0,00 \\
Paspalum conjugatum & $\mathrm{R}$ & 2,47 & 0,00 & 0,00 \\
Cleome gynandra & $\mathrm{D}$ & 2,24 & 2,32 & 0,00 \\
Imperata cylindrica & $\mathrm{R}$ & 0,00 & 6,81 & 11,11 \\
Euphorbia hirta L. & $\mathrm{D}$ & 0,00 & 5,12 & 9,37 \\
Eragrotis tenella & $\mathrm{R}$ & 0,00 & 3,83 & 0,00 \\
Eleusine indica & $\mathrm{R}$ & 0,00 & 0,00 & 6,26 \\
Lindernia ciliata & $\mathrm{D}$ & 0,00 & 0,00 & 2,54 \\
\hline Total & & 100,00 & 100,00 & 100,00 \\
\hline
\end{tabular}

Keterangan : $\mathrm{D}:$ daun lebar, $\mathrm{T}$ : tekian, $\mathrm{R}:$ rumputan

Setelah tanam, dilakukan pengambilan sampel gulma pada umur 2, 4, dan 6 minggu setelah tanam. Pengambilan sampel gulma ini diikuti dengan penyiangan pada petak percobaan tersebut. Pada pertanaman kedelai Grobogan, gulma yang dominan yaitu Bulbostylis puberula. Bulbostylis puberula termasuk golongan gulma tekian.

Tabel 3. Komposisi gulma pada pertanaman kedelai Grobogan

\begin{tabular}{lccc}
\hline \multirow{2}{*}{ Jenis gulma } & \multicolumn{3}{c}{ SDR $(\%)$} \\
\cline { 2 - 4 } & 2 minggu & 4 minggu & 6 minggu \\
\hline Tekian & 47,45 & 59,00 & 38,26 \\
Rumputan & 24,91 & 19,27 & 32,31 \\
Daun lebar & 27,65 & 21,73 & 29,42 \\
\hline
\end{tabular}

Komposisi gulma pada pertanaman kedelai Grobogan mengalami perubahan komposisi dibandingkan dengan sebelum dilakukan penanaman. Sebelum dilakukan pengolahan lahan, gulma yang dominan di lahan tersebut yaitu gulma berdaun lebar. Setelah dilakukan penanaman kedelai, gulma yang dominan di lahan pertanaman kedelai Grobogan yaitu gulma tekian. 
Tabel 4. Data pengambilan sampel gulma kedelai argomulyo

\begin{tabular}{lcccc}
\hline \multicolumn{1}{c}{ Nama Gulma } & Jenis & \multicolumn{3}{c}{ SDR $(\%)$} \\
\cline { 3 - 5 } & gulma & 2 minggu & 4 minggu & 6 minggu \\
\hline Cyperus rotundus & $\mathrm{T}$ & 24,34 & 19,89 & 11,79 \\
Cynodon dactylon & $\mathrm{R}$ & 19,94 & 8,33 & 10,11 \\
Bulbostylis puberula & $\mathrm{T}$ & 19,60 & 27,15 & 26,32 \\
Digitarias sp. & $\mathrm{R}$ & 10,58 & 0,00 & 7,78 \\
Euphorbia hirta & $\mathrm{D}$ & 5,96 & 9,03 & 3,23 \\
Richardia scabra & $\mathrm{D}$ & 5,01 & 2,96 & 2,84 \\
Amaranthus spinosus & $\mathrm{D}$ & 4,62 & 0,00 & 2,09 \\
Paspalum conjugatum & $\mathrm{R}$ & 3,67 & 0,00 & 3,53 \\
Ageratum conyzoides & $\mathrm{D}$ & 3,32 & 3,28 & 3,00 \\
Portulaca oleraceae & $\mathrm{D}$ & 2,95 & 3,44 & 0,00 \\
Eleusine indica & $\mathrm{R}$ & 0,00 & 8,58 & 0,00 \\
Imperata cylindrica & $\mathrm{R}$ & 0,00 & 7,33 & 9,24 \\
Cyperus iria & $\mathrm{T}$ & 0,00 & 5,61 & 8,34 \\
Echinochloa cruss-galli & $\mathrm{R}$ & 0,00 & 2,95 & 0,00 \\
Phyllanthus niruri & $\mathrm{D}$ & 0,00 & 1,46 & 0,00 \\
Eragrotis tenella & $\mathrm{R}$ & 0,00 & 0,00 & 11,74 \\
\hline Total & & 100,00 & 100,00 & 100,00 \\
\hline Ketan & &
\end{tabular}

Keterangan : $\mathrm{D}:$ daun lebar, $\mathrm{T}$ : tekian, $\mathrm{R}:$ rumputan

Gulma yang dominan pada awal pertanaman kedelai Argomulyo yaitu yaitu Cyperus rotundus. Cyperus rotundus termasuk golongan gulma tekian. Tetapi seiring dengan pertumbuhan tanaman kedelai, gulma Cyperus rotundus mengalami penurunan dan Bulbostylis puberula mengalami peningkatan. Hal ini disebabkan, persaingan antara tanaman budidaya dengan gulma mengakibatkan penurunan jumlah gulma tertentu.

Tabel 5. Komposisi gulma pada pertanaman kedelai argomulyo

\begin{tabular}{lccc}
\hline \multirow{2}{*}{ Jenis gulma } & \multicolumn{3}{c}{ SDR $(\%)$} \\
\cline { 2 - 4 } & 2 minggu & 4 minggu & 6 minggu \\
\hline Tekian & 43,94 & 52,64 & 46,45 \\
Rumputan & 34,20 & 27,19 & 42,39 \\
Daun lebar & 21,86 & 20,17 & 11,16 \\
\hline
\end{tabular}

Komposisi gulma pada pertanaman kedelai Argomulyo mengalami perubahan komposisi dibandingkan dengan sebelum dilakukan penanaman. Sebelum dilakukan pengolahan lahan, gulma yang dominan di lahan tersebut yaitu gulma berdaun lebar. Setelah dilakukan penanaman kedelai, gulma yang dominan di lahan pertanaman kedelai Argomulyo yaitu gulma tekian. 
Kurnia Dyah Puspita et al., / Vegetalika. 2017. 6(3): 24-36

Tabel 6. Tinggi tanaman kedelai umur 12 mst pada berbagai perlakuan penyiangan

\begin{tabular}{lc}
\hline \multicolumn{1}{c}{ Perlakuan } & Tinggi Tanaman \\
\hline Kultivar: & \\
Argomulyo & $40,95 \mathrm{a}$ \\
Grobogan & $33,48 \mathrm{~b}$ \\
\hline Peyiangan: & \\
P1 (Bebas gulma 0-panen) & $41,49 \mathrm{a}$ \\
P2 (Bebas gulma 0-2 mst) & $37,63 \mathrm{abc}$ \\
P3 (Bebas gulma 0-4 mst) & $40,94 \mathrm{a}$ \\
P4 (Bebas gulma 0-6 mst) & $41,80 \mathrm{a}$ \\
P5 (Bergulma 0-2 mst) & $29,92 \mathrm{~d}$ \\
P6 (Bergulma 0-4 mst) & $39,35 \mathrm{ab}$ \\
P7 (Bergulma 0-6 mst) & $34,07 \mathrm{bcd}$ \\
P8 (Bergulma 0-panen) & $32,51 \mathrm{~cd}$ \\
\hline Interaksi & $(-)$ \\
\hline CV (\%) & \\
\hline Keterangan: Angka dengan diikuti huruf yang berbeda menunjukkan ada beda nyata antar
\end{tabular}

Berdasarkan hasil sidik ragam terlihat bahwa kultivar kedelai dan densitas gulma berpengaruh terhadap tinggi tanaman kedelai. Pertumbuhan tinggi tanaman pada kedelai Argomulyo lebih baik dibandingkan dengan kedelai Grobogan. Tabel 6 menunjukkan perlakuan penyiangan berpengaruh terhadap tinggi tanaman kedelai. Tanaman yang disiangi selama masa awal pertumbuhan akan memiliki pertumbuhan tinggi tanaman yang lebih baik dibandingkan dengan tanaman kedelai yang tidak disiangi. Hal ini disebabkan antara gulma dan tanaman kedelai terjadi persaingan dalam memperoleh unsur hara, air, dan faktor tumbuh lainnya. Tjitrosoedirjo et al. (1984) menambahkan persaingan antara tanaman dan gulma terjadi apabila faktor kebutuhan hidup seperti hara, air, cahaya dan ruang tempat tumbuh berada dalam keadaan terbatas dan persaingan tidak terjadi apabila faktor tumbuh berada dalam keadaan cukup. 
Tabel 7. Analisis pertumbuhan tanaman kedelai pada berbagai perlakuan penyiangan

\begin{tabular}{|c|c|c|c|}
\hline Perlakuan & $\begin{array}{c}\mathrm{LAB} \\
\left(\mathrm{g} / \mathrm{cm}^{2} / \mathrm{minggu}\right)\end{array}$ & $\begin{array}{c}\text { LPT } \\
\left.\mathrm{g} / \mathrm{m}^{2} / \mathrm{minggu}\right)\end{array}$ & $\begin{array}{c}\text { LPN } \\
\text { (g/g/minggu) }\end{array}$ \\
\hline \multicolumn{4}{|l|}{ Kultivar: } \\
\hline Argomulyo & $0,063 a$ & $0,152 \mathrm{a}$ & $0,753 a$ \\
\hline Grobogan & $0,060 \mathrm{a}$ & $0,138 \mathrm{a}$ & $0,734 \mathrm{a}$ \\
\hline \multicolumn{4}{|l|}{ Peyiangan: } \\
\hline $\mathrm{P} 1$ (Bebas gulma 0-panen) & 0,063 a & $0,163 a$ & 0,753 a \\
\hline P2 (Bebas gulma $0-2 \mathrm{mst}$ ) & $0,060 \mathrm{a}$ & $0,150 a b$ & $0,738 a$ \\
\hline P3 (Bebas gulma 0-4 mst) & $0,065 a$ & $0,158 \mathrm{a}$ & $0,760 \mathrm{a}$ \\
\hline P4 (Bebas gulma 0-6 mst) & $0,060 \mathrm{a}$ & 0,158 a & $0,732 a$ \\
\hline P5 (Bergulma 0-2 mst) & $0,055 \mathrm{a}$ & $0,115 \mathrm{~b}$ & 0,720 a \\
\hline P6 (Bergulma 0-4 mst) & $0,062 \mathrm{a}$ & $0,140 a b$ & 0,750 a \\
\hline P7 (Bergulma 0-6 mst) & 0,065 a & $0,143 a b$ & $0,747 a$ \\
\hline P8 (Bergulma 0-panen) & $0,062 \mathrm{a}$ & $0,133 a b$ & $0,745 a$ \\
\hline Interaksi & $(-)$ & $(-)$ & $(-)$ \\
\hline CV (\%) & 22,12 & 21,26 & 16,22 \\
\hline
\end{tabular}

Keterangan: Angka dengan diikuti huruf yang berbeda menunjukkan ada beda nyata antar perlakuan pada uji DMRT dengan tingkat kepercayaan $95 \%$.

Pada tabel 7 menunjukkan tidak ada interaksi antara kultivar yang digunakan dengan waktu penyiangan. Berdasarkan hasil analisis pertumbuhan, perbedaan kultivar tidak berpengaruh terhadap laju asimiliasi bersih dan laju pertumbuhan tanaman. Tetapi perlakuan penyiangan, berpengaruh terhadap laju pertumbuhan tanaman. Pengendalian gulma pada areal pertanaman kedelai akan meningkatkan laju pertumbuhan tanaman. Pada areal yang dilakukan pengendalian gulma dari tanam hingga panen (P1) menunjukkan laju pertumbuhan tanaman yang lebih tinggi dibandingkan dengan perlakuan lain. Hal ini karena tidak terjadi kompetisi antara gulma dan tanaman kedelai.

Tabel 8. Bobot segar polong tanaman kedelai umur 12 mst pada berbagai perlakuan penyiangan

\begin{tabular}{lcccccccc}
\hline \multirow{2}{*}{ Perlakuan } & \multicolumn{10}{c}{ Penyiangan } \\
\cline { 2 - 9 } & P1 & P2 & P3 & P4 & P5 & P6 & P7 & P8 \\
\hline Argomulyo & $2,98 \mathrm{ab}$ & $5,05 \mathrm{a}$ & $2,93 \mathrm{ab}$ & $3,58 \mathrm{ab}$ & $1,48 \mathrm{~b}$ & $2,43 \mathrm{ab}$ & $2,49 \mathrm{ab}$ & $2,44 \mathrm{ab}$ \\
Grobogan & $2,96 \mathrm{ab}$ & $1,87 \mathrm{~b}$ & $4,21 \mathrm{ab}$ & $4,52 \mathrm{ab}$ & $3,84 \mathrm{ab}$ & $3,37 \mathrm{ab}$ & $3,12 \mathrm{ab}$ & $2,44 \mathrm{ab}$ \\
\hline Interaksi & \multicolumn{10}{c}{$(+)$} \\
\hline CV (\%) & \multicolumn{10}{c}{29,40} \\
\hline
\end{tabular}

Keterangan: Angka dengan diikuti huruf yang berbeda menunjukkan ada beda nyata antar perlakuan pada uji DMRT dengan tingkat kepercayaan $95 \%$.

Berdasarkan hasil sidik ragam terlihat bahwa terdapat interaksi antara pengaruh waktu penyiangan dan kultivar kedelai terhadap bobot segar polong kedelai. Pengaruh dari waktu penyiangan dan kultivar kedelai menunjukkan hasil yang berbeda nyata. Pada kultivar Argomulyo, waktu penyiangan yang tepat dapat meningkatkan 
Kurnia Dyah Puspita et al., / Vegetalika. 2017. 6(3): 24-36

jumlah polong pada tanaman kedelai sehingga bobot segar yang dihasilkan juga meningkat.

Tabel 9. Jumlah polong tanaman kedelai umur 12 mst pada berbagai perlakuan penyiangan

\begin{tabular}{|c|c|c|c|c|c|c|c|c|}
\hline \multirow{2}{*}{ Perlakuan } & \multicolumn{8}{|c|}{ Penyiangan } \\
\hline & P1 & P2 & P3 & P4 & P5 & P6 & P7 & P8 \\
\hline Argomulyo & $20,44 \mathrm{a}$ & $22,00 \mathrm{a}$ & $19,45 a b$ & $21,78 \mathrm{a}$ & $6,55 \mathrm{~b}$ & $14,56 a b$ & $17,67 a b$ & $10,33 a b$ \\
\hline Grobogan & $14,56 a b$ & $11,44 a b$ & $14,34 a b$ & $22,56 \mathrm{a}$ & $11,78 a b$ & $14,67 \mathrm{ab}$ & $10,22 a b$ & $14,67 a b$ \\
\hline Interaksi & \multicolumn{8}{|c|}{$(+)$} \\
\hline CV (\%) & & & & & & & & \\
\hline
\end{tabular}

Keterangan: Angka dengan diikuti huruf yang berbeda menunjukkan ada beda nyata antar perlakuan pada uji DMRT dengan tingkat kepercayaan $95 \%$.

Berdasarkan hasil sidik ragam terlihat bahwa terdapat interaksi antara pengaruh waktu penyiangan dan kultivar kedelai terhadap jumlah polong pada tanaman kedelai. Pengaruh dari waktu penyiangan dan kultivar kedelai menunjukkan hasil yang berbeda nyata. Pada kultivar Argomulyo, waktu penyiangan yang tepat dapat meningkatkan jumlah polong pada tanaman kedelai. Jumlah polong terendah yaitu pada tanaman kedelai yang dikendalikan setelah tanaman berumur 2 minggu (P5).

Tabel 10. Bobot kering polong dan bobot kering biji kedelai pada berbagai perlakuan penyiangan

\begin{tabular}{lcc}
\hline \multicolumn{1}{c}{ Perlakuan } & $\begin{array}{c}\text { Bobot kering polong } \\
\text { (gram) }\end{array}$ & $\begin{array}{c}\text { bobot kering biji } \\
\text { (gram) }\end{array}$ \\
\hline Kultivar: & $4,38 \mathrm{a}$ & $3,02 \mathrm{a}$ \\
Argomulyo & $3,70 \mathrm{~b}$ & $2,80 \mathrm{a}$ \\
Grobogan & & \\
\hline Peyiangan: & $5,24 \mathrm{a}$ & $3,83 \mathrm{a}$ \\
P1 (Bebas gulma 0-panen) & $5,27 \mathrm{a}$ & $3,87 \mathrm{a}$ \\
P2 (Bebas gulma 0-2 mst) & $5,02 \mathrm{a}$ & $3,63 \mathrm{ab}$ \\
P3 (Bebas gulma 0-4 mst) & $4,67 \mathrm{a}$ & $3,27 \mathrm{~b}$ \\
P4 (Bebas gulma 0-6 mst) & $3,78 \mathrm{~b}$ & $2,69 \mathrm{c}$ \\
P5 (Bergulma 0-2 mst) & $3,10 \mathrm{bc}$ & $2,24 \mathrm{~cd}$ \\
P6 (Bergulma 0-4 mst) & $2,42 \mathrm{c}$ & $1,76 \mathrm{~d}$ \\
P7 (Bergulma 0-6 mst) & $2,81 \mathrm{c}$ & $1,98 \mathrm{~d}$ \\
P8 (Bergulma 0-panen) & $(-)$ & $(-)$ \\
\hline Interaksi & 15,96 & 14,89 \\
\hline CV (\%) &
\end{tabular}

Keterangan: Angka dengan diikuti huruf yang berbeda menunjukkan ada beda nyata antar perlakuan pada uji DMRT dengan tingkat kepercayaan $95 \%$.

Berdasarkan hasil sidik ragam menunujukkan tidak ada interaksi antara jenis kultivar yang digunakan dengan waktu penyiangan terhadap bobot kering polong kedelai. Tabel 10 menunjukkan terdapat beda nyata bobot kering polong kedelai Argomulyo dan Grobogan. Kedelai Argomulyo memiliki bobot kering polong yang lebih besar dibandingkan kedelai Grobogan. Perlakuan penyiangan pada tanaman kedelai 
akan berpengaruh terhadap bobot kering polong yang dihasilkan. Pengendalian gulma pada tanaman kedelai akan menghasilkan bobot kering polong yang lebih berat dibandingkan tanaman kedelai yang tidak dilakukan pengendalian gulma.

Berdasarkan hasil analisis menunujukkan bahwa tidak ada interaksi antara jenis kultivar yang digunakan dengan waktu penyiangan terhadap bobot kering biji kedelai. Tabel 10 menunjukkan tidak ada beda nyata antara bobot kering biji kedelai Argomulyo dengan kedelai Grobogan. Kedelai Argomulyo memiliki bobot kering biji yang lebih besar dibandingkan kedelai Grobogan. Pada Tabel 10 penyiangan pada tanaman kedelai berpengaruh terhadap bobot kering biji yang dihasilkan. Pengendalian gulma pada tanaman kedelai akan menghasilkan bobot kering biji yang lebih berat dibandingkan tanaman kedelai yang tidak dilakukan pengendalian gulma.

Tabel 11. Indeks panen dan hasil panen aktual tanaman kedelai pada berbagai perlakuan penyiangan

\begin{tabular}{lcc}
\hline \multicolumn{1}{c}{ Perlakuan } & Indeks panen & $\begin{array}{c}\text { Hasil panen aktual } \\
\text { (ton/ha) }\end{array}$ \\
\hline Kultivar: & $0,60 \mathrm{a}$ & $1,12 \mathrm{a}$ \\
Argomulyo & $0,58 \mathrm{a}$ & $1,04 \mathrm{a}$ \\
Grobogan & & \\
\hline Peyiangan: & $0,66 \mathrm{a}$ & $1,43 \mathrm{a}$ \\
P1 (Bebas gulma 0-panen) & $0,67 \mathrm{a}$ & $1,44 \mathrm{a}$ \\
P2 (Bebas gulma 0-2 mst) & $0,65 \mathrm{a}$ & $1,35 \mathrm{ab}$ \\
P3 (Bebas gulma 0-4 mst) & $0,61 \mathrm{ab}$ & $1,22 \mathrm{~b}$ \\
P4 (Bebas gulma 0-6 mst) & $0,56 \mathrm{cb}$ & $1,00 \mathrm{c}$ \\
P5 (Bergulma 0-2 mst) & $0,53 \mathrm{c}$ & $0,84 \mathrm{~cd}$ \\
P6 (Bergulma 0-4 mst) & $0,54 \mathrm{c}$ & $0,66 \mathrm{~d}$ \\
P7 (Bergulma 0-6 mst) & $0,51 \mathrm{c}$ & $0,74 \mathrm{~d}$ \\
P8 (Bergulma 0-panen) & $(-)$ & $(-)$ \\
\hline Interaksi & 8.24 & 14.83 \\
\hline CV (\%) & 0.24
\end{tabular}

Keterangan: Angka dengan diikuti huruf yang berbeda menunjukkan ada beda nyata antar perlakuan pada uji DMRT dengan tingkat kepercayaan $95 \%$.

Indeks panen menunjukkan perbandingan distribusi hasil asimilasi antara biomassa ekonomi dengan biomassa keseluruhan. Indeks panen tanaman dapat ditingkatkan dengan cara meningkatkan biomassa ekonomis yang dihasilkan. Tabel 11 menunujukkan tidak ada interaksi antara jenis kultivar yang digunakan dengan waktu penyiangan terhadap indeks panen tanaman kedelai. Tabel 11 menunjukkan hasil tidak ada beda nyata antara indeks panen tanaman kedelai Argomulyo dan Grobogan. Tetapi perlakuan penyiangan pada tanaman kedelai menunjukkan hasil yang berbeda nyata. Penyiangan pada tanaman kedelai berpengaruh terhadap indeks panen yang dihasilkan. Penyiangan pada tanaman kedelai akan menghasilkan indeks panen yang lebih besar dibandingkan tanaman kedelai yang tidak dilakukan penyiangan. Semakin 
Kurnia Dyah Puspita et al., / Vegetalika. 2017. 6(3): 24-36

tinggi nilai indeks panen maka akan semakin besar pula kemungkinan memperoleh hasil kedelai yang maksimal.

Hasil panen aktual merupakan salah satu parameter yang digunakan untuk menghitung hasil dalam satuan ton/ha. Tabel 11 menunjukkan hasil analisis panen aktual tanaman kedelai pada berbagai perlakuan penyiangan. Hasil analisis menunjukkan bahwa perlakuan penyiangan tidak memiliki pengaruh beda nyata antara kultivar Agromulyo dengan Grobogan. Sedangkan waktu penyiangan berpengaruh terhadap hasil panen aktual tanaman kedelai. Tanaman kedelai yang dilakukan penyiangan menunjukkan hasil panen yang lebih tinggi dibandingkan dengan tanaman kedelai yang tidak dilakukan penyiangan.

Menurut Khalil (2003), penurunan komponen hasil seperti jumlah polong dan jumlah biji disebabkan karena terjadinya persaingan antar tanaman dengan meningkatnya densitas gulma. Tanaman kedelai yang tumbuh bersama gulma menyebabkan tingkat pertumbuhan tanaman terhambat, daun lebih jarang, serta polong berukuran lebih kecil dibanding dengan kedelai yang tumbuh tanpa gulma. Semakin besar populasi gulma mengakibatkan semakin tertekannya pertumbuhan dan semakin rendah polong kedelai yang dihasilkan.

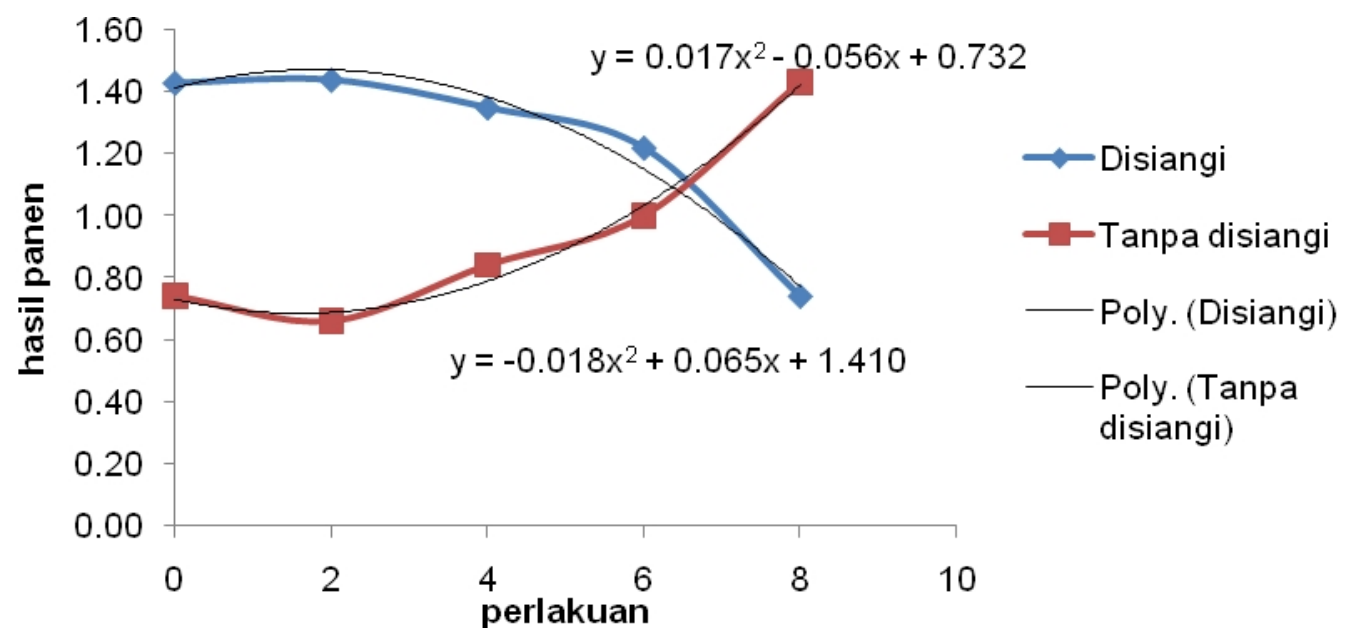

Gambar 2.Grafik fungsi hasil panen aktual antara tanaman kedelai yang dilakukan pengendalian gulma dan tanpa pengendalian gulma

Berdasarkan gambar 2 dapat terlihat bahwa perlakuan pengendalian gulma berpengaruh terhadap hasil panen kedelai. Gulma yang tidak dilakukan penyiangan akan mengalami peningkatan bobot kering gulma. Hal ini karena populasi gulma di lahan semakin meningkat sehingga meningkatkan bobot kering gulma. Semakin besar bobot kering gulma menunjukkan persaingan tanaman kedelai dengan gulma semakin 
besar. Persaingan yang semakin besar ini akan berpengaruh terhadap pertumbuhan dan hasil tanaman kedelai. Pertanaman kedelai yang tertekan oleh pertumbuhan gulma menyebabkan pertumbuhan tanaman kurang optimal sehingga menghambat laju asimilasi tanaman yang dapat menyebabkan penurunan hasil kedelai. Berdasarkan grafik fungsi di atas (Gambar 2), dapat diketahui periode kritis tanaman kedelai Grobogan dan Argomulyo yaitu dari sejak tanam hingga tanaman berumur 6 minggu.

\section{KESIMPULAN}

1. Waktu penyiangan berpengaruh terhadap pertumbuhan dan hasil dua kultivar kedelai.

2. Periode kritis tanaman kedelai kultivar Grobogan dan kultivar Argomulyo yaitu pada umur 0-6 minggu setelah tanam.

3. Gulma yang dominan pada pertanaman kedelai Grobogan yaitu Bulbostylis puberula. Gulma yang dominan pada pertanaman kedelai Argomulyo yaitu Cyperus rotundus.

\section{UCAPAN TERIMAKASIH}

Pada kesempatan ini penulis mengucapkan terima kasih kepada kedua orang tua atas bantuan dana sehingga penelitian dapat berjalan dengan baik. Teman-teman satu angkatan yang telah memberikan banyak bantuan dalam penulisan skripsi ini.

\section{DAFTAR PUSTAKA}

Atman. 2006. Budidaya kedelai di lahan sawah Sumatera Barat. Jurnal Ilmiah Tambua. 5(3): 288-296

Khalil, M. 2003. Komponen hasil tanaman kedelai varietas kipas putih pada berbagai densitas dan pemupukan. Jurnal Eugenia. 9(3):161-164.

Manurung, J.P. dan E. Syam'un. 2003. Hubungan komponen hasil dengan hasil kedelai (Glycine max (L.) Merr.) yang ditanam pada lahan diolah berbeda sistem dan berasosiasi dengan gulma. Jurnal Agrivigor. 3(2):179-188.

Mercado, B.L. 1979. Introduction to weed science. Southeast Asia Regional Centre for Graduate Study and Research in Agriculture. Los Banos, Laguna, Philippines.

Moenandir, J. 1993. Pengantar ilmu dan pengendalian gulma. PT. Rajawali Press, Jakarta.

Siregar, M. 2003. Kebijakan perdagangan dan daya saing komoditas kedelai. PSE Balitbang Pertanian, Departemen Pertanian Republik Indonesia, Bogor. 
Kurnia Dyah Puspita et al., / Vegetalika. 2017. 6(3): 24-36

Soerjani, M., M. Soendaru dan C. Anwar. 1996. Present status of weed problems and their control in Indonesia. Biotrop. Special Publication.

Sudaryanto, T. dan D.K.S. Swastika, 2007. Ekonomi kedelai di Indonesia. Forum Agro Ekonomi (FAE) 12 (3) : 1-27.

Tjitrosoedirdjo, S., I.H. Utomo dan J. Wiroatmojo. 1984. Pengelolaan Gulma di Perkebunan. PT. Gramedia Pustaka Utama. Jakarta.

Zimdahl, R.L. 2004.Weed Crop Competition: a Review. Second Edition. Blackwell Publishing. Australia. 